\title{
Lack of association between PRNP I 368 polymorphism and Alzheimer's disease or vascular dementia
}

\author{
Byung-Hoon Jeong ${ }^{1}$, Kyung-Hee Lee ${ }^{2}$, Yun-Jung Lee ${ }^{1}$, Yun Joong Kim¹, Eun- \\ Kyoung Choi ${ }^{1}$, Young-Hoon Kim², Young-Sook $\mathrm{Cho}^{2}$, Richard I Carp ${ }^{3}$ and \\ Yong-Sun Kim*1
}

\begin{abstract}
Address: ${ }^{1}$ Ilsong Institute of Life Science, Hallym University, 1605-4 Gwanyang-dong, Dongan-gu, Anyang, Gyeonggi-do 431-060, South Korea, ${ }^{2}$ Samkwang Medical Laboratories, 9-60, Yangjae-dong, Seocho-gu, Seoul 137-887, South Korea and ${ }^{3}$ New York State Institute for Basic Research in Developmental Disabilities, Staten Island, NY 10314, USA

Email: Byung-Hoon Jeong - bhjeong@hallym.ac.kr; Kyung-Hee Lee - puremind72@empal.com; Yun-Jung Lee - jjung0301@ hallym.ac.kr; Yun Joong Kim - yunkim@ @allym.ac.kr; Eun-Kyoung Choi - ekchoi@hallym.ac.kr; Young-Hoon Kim - sml-yh@smlab.co.kr; YoungSook Cho - yscho@smlab.co.kr; Richard I Carp - Richard.carp@omr.state.ny.us; Yong-Sun Kim* - yskim@hallym.ac.kr

* Corresponding author
\end{abstract}

Published: 8 April 2009

BMC Medical Genetics 2009, 10:32 doi:10.1 186/1471-2350-10-32
Received: 29 August 2008

Accepted: 8 April 2009

This article is available from: http://www.biomedcentral.com//47I-2350/I0/32

(C) 2009 Jeong et al; licensee BioMed Central Ltd.

This is an Open Access article distributed under the terms of the Creative Commons Attribution License (http://creativecommons.org/licenses/by/2.0), which permits unrestricted use, distribution, and reproduction in any medium, provided the original work is properly cited.

\begin{abstract}
Background: Polymorphisms of the prion protein gene (PRNP) at codons 129 and 219 play an important role in the susceptibility to Creutzfeldt-Jakob disease (CJD), and might be associated with other neurodegenerative disorders. Several recent reports indicate that polymorphisms outside the coding region of PRNP modulate the expression of prion protein and are associated with sporadic CJD, although other studies failed to show an association. These reports involved the polymorphism PRNP I 368 which is located upstream from PRNP exon I. In a case-controlled protocol, we assessed the possible association between the PRNP I 368 polymorphism and either Alzheimer's disease $(A D)$ or vascular dementia $(\mathrm{VaD})$.
\end{abstract}

Methods: To investigate whether the PRNP I 368 polymorphism is associated with the occurrence of $A D$ or $V a D$ in the Korean population, we compared the genotype, allele, and haplotype frequencies of the PRNP 1368 polymorphism in $152 \mathrm{AD}$ patients and $192 \mathrm{VaD}$ patients with frequencies in 268 healthy Koreans.

Results and conclusion: Significant differences in genotype, allele and haplotype frequencies of PRNP I 368 polymorphism were not observed between $A D$ and normal controls. There were no significant differences in the genotype and allele frequencies of the PRNP I368 polymorphism between Korean $\mathrm{VaD}$ patients and normal controls. However, in the haplotype analysis, haplotype $\mathrm{Ht} 5$ was significantly over-represented in Korean $\mathrm{VaD}$ patients. This was the first genetic association study of a polymorphism outside the coding region of PRNP in relation to AD and VaD.

\section{Background}

Alzheimer's disease (AD), the most common cause of dementia in the aged population, is associated with progressive memory deterioration and disordered cognitive function resulting from a loss of cholinergic transmission and characterized neuropathologically by the presence of neurofibrillary tangles and amyloid plaques in the brain and clinically by gradual loss of memory. These changes 
may result from destructive processes involving the disruption of microtubule assembly and synaptic loss. Further neuronal damage and disease progression are consequences of this damage. Although the processes involved in $\mathrm{AD}$ could be triggered by many environmental factors, genetic studies have shown that in some cases mutations and polymorphisms of particular genes can confer susceptibility to the degenerative process. Several genes associated with AD have been identified, including amyloid precursor protein gene $(A P P)$, presenilin-1 gene (PS1), presenilin-2 gene (PS2), and the apolipoprotein E gene $(A p o E)[1] . \mathrm{AD}$ and prion diseases, such as Creutzfeldt-Jakob disease (CJD), share a number of clinical, pathogenetic and pathological features. A structural hallmark of $\mathrm{AD}$ is amyloid- $\beta$ peptide $(\mathrm{A} \beta)$ aggregates in extracellular amyloid deposits defined as senile plaques, while in CJD there is an accumulation of abnormal proteaseresistant isoform (PrPres) in neurons and in extracellular amyloid-like aggregates. $\mathrm{A} \beta$-positive senile plaques in $\mathrm{AD}$ brains commonly contain $\mathrm{PrPC}^{\mathrm{C}}$ deposits [2-4] and incidental A $\beta$-positive senile plaques in prion diseases such as CJD may also be positive for $\operatorname{PrPC}$ [5].

Vascular dementia (VaD) is the second most common cause of dementia after $\mathrm{AD}$. $\mathrm{VaD}$ is a clinical syndrome causing cognitive decline due to cerebrovascular lesions. Risk factors for $\mathrm{VaD}$ are age, sex, race, hypertension, smoking, diabetes mellitus, and hypercholesterolemia. However, there is no conclusive evidence for the association of genetic polymorphisms with $\mathrm{VaD}$. VaD and prion diseases share some pathophysiological similarities, such as the occurrence of dementia.

Prion protein contains 253 amino acids encoded by prion protein gene (PRNP), located on chromosome 20p12.3 in humans. PRNP plays an important role in conferring susceptibility or resistance to prion disease. A number of mutations in the open reading frame (ORF) are linked to the familial form of prion diseases [6,7]. Polymorphisms at codons 129 or 219 of PRNP are susceptibility factors to sporadic CJD [8-11]. In several European populations, an association between the PRNP codon 129 polymorphism and $\mathrm{AD}$ was reported [12-15]. In contrast to these studies, other studies failed to detect a significant association between this polymorphism and AD [16-18], and in Asian populations, no association between the PRNP codons $129 / 219$ polymorphisms and AD was reported [19]. Recently, the polymorphism (PRNP 1368) in an upstream of PRNP exon 1 was found to be associated with sporadic CJD in British and German populations [20,21], but this association was not seen in Dutch and Korean populations [22,23]. This polymorphism was studied in other diseases in addition to sporadic CJD. In a British population, there was no association of PRNP 1368 polymorphism with frontotemporal lobar degeneration (FTLD) [24]. Although PRNP 1368 polymorphism has been stud- ied in sporadic CJD and FTLD patients, a case-controlled association study between the PRNP 1368 polymorphism and either $\mathrm{AD}$ or $\mathrm{VaD}$ has not been reported thus far.

In the present study, the purpose was to investigate the genotype and allele frequency of a polymorphism outside the coding region of PRNP in Korean $\mathrm{AD}$ and $\mathrm{VaD}$ patients and to determine the correlation between this polymorphism and the incidence of $\mathrm{AD}$ and $\mathrm{VaD}$ in the Korean population.

\section{Methods \\ Subjects}

Analysis included 152 Korean patients with AD (51 male and 101 female; mean age at disease onset $73.48 \pm 8.00$ years), which were diagnosed according to the National Institute of Neurological and Communicative Disorders and Stroke-Alzheimer's Disease and Related Disorders Association (NINCDS-ADRDA) criteria [25] with minor modification specifying the gradual onset and progression of memory loss with a duration of at least 12 months. None of these patients reported family history of AD. All AD patients were gathered from Chunchon, South Korea and were examined in the Department of Neurology, Chunchon Sacred Heart Hospital. General medical and neurological examinations, neuropsychological testing, and computed topography scans were performed to exclude other forms of dementia. Blood samples were collected from 152 AD patients between May 2000 and June 2005. One hundred ninety two Korean patients with $\mathrm{VaD}$ (100 male and 92 female; mean age: $71.95 \pm 8.92$ years) were diagnosed according to the Diagnostic and Statistical Manual of Mental Disorders, Fourth Edition (DSM-IV) [26] and National Institute of Neurological Disorders and Stroke-Association Internationale pour la Recherche et l'Enseignement en Neurosciences (NINDS-AIREN) criteria [27] after clinical examination and neuropsychological testing, including minimental state examination (MMSE). VaD patients were gathered from Anyang, South Korea and were examined in the Department of Neurology, Hallym University Hospital. Blood samples were collected from $192 \mathrm{VaD}$ patients between May 2000 and June 2008. The control subjects were 268 unrelated individuals (118 male and 150 female; mean age $71.17 \pm 8.68$ years) matched for age and ethnic background to $\mathrm{AD}$ patients and $\mathrm{VaD}$ patients (Table 1 ). All control subjects were volunteers recruited from routine health checkups at the Chunchon Sacred Heart Hospital. None of them presented symptoms of dementia or any movement disorders. Absence of dementia was determined by considering past history and Korean MMSE criterion (score of >24). Blood samples were collected from 268 healthy Korean volunteers between May 2000 and June 2005. The study was approved by the Ethical Committee of Chunchon Sacred Heart Hospital and an informed consent was given by all subjects or their caregivers. All blood samples were frozen at $-70^{\circ} \mathrm{C}$ prior to analysis. 
Table I: Characteristics of AD and VaD patients and controls

\begin{tabular}{|c|c|c|c|c|c|}
\hline & Control & $A D$ & $P$ value $^{a}$ & $\mathrm{VaD}$ & $P$ value ${ }^{a}$ \\
\hline Number of subjects & 268 & 152 & & 192 & \\
\hline \multicolumn{6}{|l|}{ Gender } \\
\hline Male, n (\%) & $118(44.0 \%)$ & $5 \mathrm{I}(33.55 \%)$ & 0.014 & $100(52.1 \%)$ & 0.090 \\
\hline Female, $\mathrm{n}(\%)$ & $150(56.0 \%)$ & $101(66.45 \%)$ & & $92(47.9 \%)$ & \\
\hline Mean age at disease onset (years $\pm S D$ ) & - & $73.48 \pm 8.00$ & 0.006 & $71.95 \pm 8.92$ & 0.348 \\
\hline Mean age at blood collection (years \pm SD) & $71.17 \pm 8.68$ & - & & - & \\
\hline
\end{tabular}

aBased on the difference between controls and $A D$ or $\mathrm{VaD}$ patients

\section{Genotyping}

Genomic DNA was extracted from $200 \mu$ l blood using the QIAamp DNA blood mini kit (Qiagen, USA) following the supplier's instructions. Polymerase chain reaction (PCR) was performed with J-1 (GAGAAAACCTTGCGTCAGCA) and J-2 (AAGGTGCAGAAAAGATGGGC) primers. These primers were designed to amplify a 586 bp product in an upstream region of PRNP exon 1 . The PCR reagents contained 50 pmole of each primer, $5 \mu$ l of $10 \times$ Taq DNA polymerase buffer, $1.5 \mathrm{mM} \mathrm{MgCl}_{2}, 0.2 \mathrm{mM}$ of each dNTP mixtures, and 2.5 units of Taq DNA polymerase (Promega, USA). The PCR conditions were $94^{\circ} \mathrm{C}$ for 2 min to denature, and 35 cycles of $94^{\circ} \mathrm{C}$ for $45 \mathrm{sec}, 56^{\circ} \mathrm{C}$ for $45 \mathrm{sec}$, and $72^{\circ} \mathrm{C}$ for $1 \mathrm{~min} 30 \mathrm{sec}$, and then 1 cycle of $72^{\circ} \mathrm{C}$ for $10 \mathrm{~min}$ to extend the reaction. The Perkin-Elmer Cetus DNA thermal cycler (Pekin-Elmer, USA) was used. Restriction cleavage sites were searched using Webcutter, ver. 2.0 (Carolina Biological Supply Co., USA). A $20 \mu \mathrm{l}$ aliquot of purified PCR mixture was digested at $37^{\circ} \mathrm{C}$ for $1 \mathrm{~h}$ with 5 units of Pvu II (Invitrogen, USA). Restriction products were separated on a $1.5 \%$ agarose gel and visualized with ethidium bromide staining under UV light. The purification of PCR products for sequencing was done using a QIAquick gel extraction kit (Qiagen, USA). The PCR products were directly sequenced on an ABI 377 automatic sequencer using a Taq dideoxy terminator cycle sequencing kit (ABI, USA) and the same primers as indicated earlier in the standard conditions.

\section{Statistical analyses}

A $\chi^{2}$ test was used to determine whether the PRNP 1368 polymorphism was in Hardy-Weinberg equilibrium (HWE) in the Korean population. Odds ratios (OR) with 95\% confidence interval (CI) and $P$-values were calculated by using the codominant model, controlling for age and sex as covariates. Differences in age of populations were analyzed using Student's $t$-test, and sex differences by using $\chi^{2}$ test. Haplotypes and their frequencies were inferred using the algorithm developed by Stephens et al. [28]. Fisher's exact test was used to analyze differences in haplotype frequency between the normal population and patients with $\mathrm{AD}$ and $\mathrm{VaD}$. The statistical powers were calculated using Statistical Power Calculator http://www.dss research.com/toolkit/spcalc/power_p2.asp.

\section{Results}

The genotype frequencies at PRNP 1368 were in HWE in Korean control group $(P=0.742)$ and $\operatorname{AD}$ group $(P=$ $0.226)$, not in $\mathrm{VaD}$ group $(P=0.025)$ (data not shown). To examine a correlation between the PRNP 1368 polymorphism and susceptibility of AD in Koreans, we examined the genotype and allele frequencies of this polymorphism in 152 Korean AD patients and in 268 healthy controls. No significant difference between Korean $\mathrm{AD}$ patients and controls was found in genotype or allele frequency of the PRNP 1368 polymorphism (Table 2). This result suggests that the PRNP 1368 polymorphism does not increase susceptibility to AD. When our data set was stratified by gender, there was no significant association between this polymorphism and $\mathrm{AD}$ (data not shown).

We also investigated the genotype and allele frequencies of PRNP 1368 in 192 Korean VaD patients to determine whether this polymorphism correlated with $\mathrm{VaD}$. There were no significant differences in genotype and allele frequencies between $\mathrm{VaD}$ patients and controls (Table 2). In addition, analysis of the haplotype frequency was performed in $\mathrm{AD}$ patients, $\mathrm{VaD}$ patients and controls. Six haplotypes of the 3 PRNP polymorphisms were constructed in Koreans. One (ht 5) of these six haplotypes was significantly over-represented in Korean $\mathrm{VaD}$ patients (Table 3).

\section{Discussion}

In this study, we failed to detect a significant association between the PRNP 1368 polymorphism and the occurrence of either $\mathrm{AD}$ or $\mathrm{VaD}$ in the Korean population.

There is the possibility that the PRNP 1368 polymorphism is not functional with regard to affecting the level of $\mathrm{PrPC}^{\mathrm{C}}$. Another possibility is that a false negative result was obtained due to statistical powers. Data for AD and $\mathrm{VaD}$ patients showed a statistical power of $19.1 \%$ and $11.2 \%$, respectively, at the Type I error rate of 0.05 compared with healthy controls. The statistical powers aren't high enough for ensuring that the PRNP 1368 polymorphism is not relevant to prion replication. However, in the haplotype analysis among 3 PRNP polymorphisms, hap- 
Table 2: Genotype and allele frequencies of the PRNP 1368 polymorphism in the normal population, AD patients, and VaD patients

\begin{tabular}{|c|c|c|c|c|c|c|c|c|c|}
\hline & \multirow{2}{*}{$\begin{array}{c}\text { Control } \\
(n=268)\end{array}$} & \multirow{2}{*}{$\begin{array}{c}A D \\
(n=152)\end{array}$} & \multirow{2}{*}{$\begin{array}{c}\mathrm{VaD} \\
(\mathrm{n}=192)\end{array}$} & \multicolumn{3}{|c|}{$A D$ vs Control } & \multicolumn{3}{|c|}{$\mathrm{VaD}$ vs control } \\
\hline & & & & $\mathrm{OR}^{\mathrm{a}}$ & $95 \% \mathrm{Cl}^{\mathrm{b}}$ & $P$ value & OR & $\begin{array}{c}95 \% \\
\mathrm{Cl}\end{array}$ & $P$ value \\
\hline \multicolumn{10}{|c|}{ Genotype frequency } \\
\hline $\mathrm{CC}$ & $103(38.4)$ & $56(36.8)$ & $84(43.8)$ & - & - & - & - & - & - \\
\hline $\mathrm{CT}$ & $124(46.3)$ & 67 (44.I) & 74 (38.5) & 0.994 & $0.640-1.544$ & 0.978 & 0.732 & $0.487-1.100$ & 0.133 \\
\hline TT & $4 \mid(I 5.3)$ & $29(20.1)$ & 34 (I7.7) & 1.301 & $0.731-2.315$ & 0.371 & 1.017 & $0.594-1.742$ & 0.952 \\
\hline \multicolumn{10}{|c|}{ Allele frequency } \\
\hline C & $330(6 \mid .6)$ & 179 (58.9) & $242(63.0)$ & - & - & - & - & - & - \\
\hline $\mathrm{T}$ & $206(38.4)$ & $125(4 \mid .1)$ & $142(37.0)$ & 1.119 & $0.839-1.491$ & 0.444 & 0.940 & $0.717-1.232$ & 0.654 \\
\hline
\end{tabular}

Figures in parentheses are percentages

aOdds ratio

bConfidence interval

lotype ht5 was the only haplotype significantly associated with $\operatorname{VaD}(\mathrm{p}=0.013)$ (Table 3$)$ and the genotype frequency of PRNP 1368 polymorphism in VaD patients was not in HWE. These results suggested some interaction among 3 PRNP polymorphisms in the determination of $\mathrm{VaD}$ risk and were needed for further evaluation of the association of PRNP 1368 polymorphism with VaD in other ethnic groups.

Although the exact function of the prion protein is not fully understood, it might be involved in the development and intensity of oxidative stress and, thereby, contribute to neurodegeneration. Thus, polymorphisms in the coding region of PRNP might influence other neurodegenerative disorders in addition to prion diseases. Many studies on a correlation between the PRNP codon 129 and AD in various populations have yielded contradictory results [12-19]. This controversial result may be due to the different sample size of the population analyzed, to a difference in frequency of PRNP genotypes between different ethnic groups [29], or even to a difference in age of onset. In our previous studies, we failed to detect a significant association between PRNP polymorphism at codons 129/219 and the risk for $\mathrm{AD}$ or $\mathrm{VaD}$ in the Korean population $[30,31]$.
Recently, there has been growing concern about several polymorphisms outside the ORF of PRNP, as there is evidence that levels of PRNP expression influence incubation time and the susceptibility to prion diseases. Polymorphisms in the PRNP promoter region may be associated with increased susceptibility of prion diseases in cattle and mice [32-34]. These PRNP promoter polymorphisms influence the PRNP gene expression level [35]. Overexpression of $P R N P$ in transgenic mice led to a decrease in incubation time, whereas PRNP knockout mice were resistant to prion disease after infection [36,37]. Therefore, we suggest that the polymorphism of PRNP 1368, located in the promoter region, may influence the expression of the PRNP gene; the promoter polymorphisms of PRNP might also be associated with other neurodegenerative diseases. In previous studies, several polymorphisms were identified in intronic and upstream regions of human PRNP. The single nucleotide polymorphism (SNP) at position -101 (PRNP 12533) within the regulatory region of PRNP was associated with sporadic CJD in the British population [38], but not in samples derived from Dutch and German populations [20,39].

Even though these results did not show a relationship between PRNP 1368 and $\mathrm{AD}$ or $\mathrm{VaD}$, it would be useful to

Table 3: Haplotype frequency of three PRNP polymorphisms in the normal population, AD patients, and VaD patients

\begin{tabular}{|c|c|c|c|c|c|c|c|c|c|}
\hline \multirow[t]{2}{*}{ Haplotypes } & \multirow[t]{2}{*}{1368} & \multirow[t]{2}{*}{ Codon 129} & \multirow[t]{2}{*}{ Codon 219} & \multicolumn{3}{|c|}{ Frequency } & \multicolumn{3}{|c|}{$P$ value } \\
\hline & & & & $A D$ & $\mathrm{VaD}$ & Control & $A D$ vs Control & $\mathrm{VaD}$ vs Control & $A D$ vs $\mathrm{VaD}$ \\
\hline htl & $\mathrm{C}$ & $A$ & G & 0.5592 & 0.5622 & 0.5951 & - & - & - \\
\hline ht2 & $\mathrm{T}$ & $A$ & G & 0.3618 & 0.3623 & 0.3450 & 0.479 & 0.451 & 0.996 \\
\hline ht3 & $\mathrm{T}$ & $A$ & $A$ & 0.0263 & 0.0142 & 0.0292 & 0.990 & 0.167 & 0.215 \\
\hline ht4 & $\mathrm{T}$ & G & G & 0.0197 & 0.0037 & 0.0115 & 0.280 & 0.252 & 0.050 \\
\hline ht5 & $\mathrm{C}$ & $A$ & $A$ & 0.0164 & 0.0352 & 0.0109 & 0.333 & 0.013 & 0.226 \\
\hline ht6 & $\mathrm{C}$ & G & G & 0.0066 & 0.0224 & 0.0083 & 1.0 & 0.078 & 0.197 \\
\hline
\end{tabular}


assess associations between $\mathrm{AD} / \mathrm{VaD}$ and other PRNP polymorphisms in the promoter region, including the PRNP 12533 polymorphism.

\section{Conclusion}

PRNP 1368 polymorphism was not significantly associated with incidence of sporadic $\mathrm{AD}$ and $\mathrm{VaD}$ in Koreans. However, in the haplotype analysis among 3 PRNP polymorphisms, we observed a significant association between haplotype ht5 and VaD. Our report is the first association study of a polymorphism outside the coding region of $P R N P$ with $\mathrm{AD}$ and $\mathrm{VaD}$.

\section{Competing interests}

The authors declare that they have no competing interests.

\section{Authors' contributions}

BHJ and YSK designed the study. BHJ, KHL, and YJL performed the genotyping. BHJ, YJK, EKC, YHK, YSC, and YSK analyzed the data. BHJ, EKC, and YJK performed statistical analysis. BHJ, YJK, RIC, and YSK wrote the paper. All authors read and approved the final manuscript.

\section{Acknowledgements}

This work was supported by the Korea Research Foundation Grant funded by the Korean Government (MOEHRD) (KRF-2006-3 I I-E00034).

\section{References}

I. Bertram L, Tanzi RE: The genetic epidemiology of neurodegenerative disease. J Clin Invest 2005, I I 5: I 449- I 457.

2. Esiri MM, Carter J, Ironside JW: Prion protein immunoreactivity in brain samples from an unselected autopsy population: findings in 200 consecutive cases. Neuropathol Appl Neurobiol 2000, 26:273-284.

3. Ferrer I, Blanco R, Carmona M, Puig B, Ribera R, Rey MJ, Ribalta T: Prion protein expression in senile plaques in Alzheimer's disease. Acta Neuropathologica 200I, 10 I:49-56.

4. Kovács GG, Head MW, Hegyi I, Bunn TJ, Flicker H, Hainfellner JA, McCardle L, László L, Jarius C, Ironside JW, Budka H: Immunohistochemistry for the prion protein: comparison of different monoclonal antibodies in human prion disease subtypes. Brain Pathol 2002, I 2: I- II.

5. Hainfellner JA, Wanschitz J, Jellinger K, Liberski PP, Gullotta F, Budka $\mathrm{H}$ : Coexistence of Alzheimer-type neuropathology in Creutzfeldt-Jakob disease. Acta Neuropathol 1998, 96:116-122.

6. Mead S: Prion disease genetics. Eur J Hum Genet 2006, 14:273-28I.

7. Kovacs GG, Puopolo M, Ladogana A, Pocchiari M, Budka H, van Duijn C, Collins SJ, Boyd A, Giulivi A, Coulthart M, Delasnerie-Laupretre N, Brandel JP, Zerr I, Kretzschmar HA, de Pedro-Cuesta J, Calero-Lara M, Glatzel M, Aguzzi A, Bishop M, Knight R, Belay G, Will R, Mitrova E, EUROCJD: Genetic prion disease: the EUROCJD experience. Hum Genet 2005, I I 8:166-174.

8. Petraroli R, Pocchiari M: Codon 219 polymorphism of PRNP in healthy Caucasians and Creutzfeldt-Jakob disease patients. Am J Hum Genet 1996, 58:888-889.

9. Jeong BH, Lee KH, Kim NH, Jin JK, Kim JI, Carp RI, Kim YS: Association of sporadic Creutzfeldt-Jakob disease with homozygous genotypes at PRNP codons 129 and 219 in the Korean population. Neurogenetics 2005, 6:229-232.

10. Palmer MS, Dryden AJ, Hughes JT, Collinge J: Homozygous prion protein genotype predisposes to sporadic Creutzfeldt-Jakob disease. Nature 1991, 352:340-342.

11. Shibuya S, Higuchi J, Shin RW, Tateishi J, Kitamoto T: Codon 219 Lys allele of PRNP is not found in sporadic Creutzfeldt-Jakob disease. Ann Neurol 1998, 43:826-828.
12. Dermaut B, Croes EA, Rademakers R, Broeck M Van den, Cruts M, Hofman A, van Duijn CM, Van Broeckhoven C: PRNP Vall 29 homozygosity increases risk for early-onset Alzheimer's disease. Ann Neurol 2003, 53:409-4I2.

13. Gacia M, Safranow K, Styczyñska M, Jakubowska K, Pepłoñska B, Chodakowska-Zebrowska M, Przekop I, Słowik A, Golañska E, HułasBigoszewska K, Chlubek D, Religa D, Zekanowski C, Barcikowska M: Prion protein gene MI29 allele is a risk factor for Alzheimer's disease. J Neural Transm 2006, I I 3:1747-I75I.

14. Golanska E, Hulas-Bigoszewska K, Rutkiewicz E, Styczynska M, Peplonska B, Barcikowska M, Bratosiewicz-Wasik J, Liberski PP: Polymorphisms within the prion (PrP) and prion-like protein (Doppel) genes in AD. Neurology 2004, 62:3 I3-315.

15. Riemenschneider M, Klopp N, Xiang W, Wagenpfeil S, Vollmert C, Muller U, Forstl H, Illig T, Kretzschmar H, Kurz A: Prion protein codon 129 polymorphism and risk of Alzheimer disease. Neurology 2004, 63:364-366.

16. Casadei VM, Ferri C, Calabrese E, Grimaldi LM, Franceschi M, Veglia $F$, Licastro F, Mariani C: Prion protein gene polymorphism and Alzheimer's disease: one modulatory trait of cognitive decline? J Neurol Neurosurg Psychiatry 200 I, 7 I:279-280.

17. Combarros O, Sánchez-Guerra M, Llorca J, Alvarez-Arcaya A, Berciano J, Peña N, Fernández-Viadero C: Polymorphism at codon 129 of the prion protein gene is not associated with sporadic AD. Neurology 2000, 55:593-595.

18. Del Bo R, Scarlato M, Ghezzi S, Martinelli-Boneschi F, Fenoglio C, Galimberti G, Galbiati S, Virgilio R, Galimberti D, Ferrarese C, Scarpini E, Bresolin N, Comi GP: Is MI29V of PRNP gene associated with Alzheimer's disease? A case-control study and a meta-analysis. Neurobiol Aging 2006, 27:770el-770.e5.

19. Ohkubo T, Sakasegawa $Y$, Asada T, Kinoshita T, Goto $Y$, Kimura $H$, Mizusawa H, Hachiya NS, Kaneko K: Absence of association between codon $129 / 219$ polymorphisms of the prion protein gene and Alzheimer's disease in Japan. Ann Neurol 2003, 54:553-554

20. Vollmert C, Windl O, Xiang W, Rosenberger A, Zerr I, Wichmann HE, Bickeböller H, Illig T, KORA group, Kretzschmar HA: Significant association of a MI29V independent polymorphism in the 5' UTR of the PRNP gene with sporadic CreutzfeldtJakob disease in a large German case-control study. J Med Genet 2006, 43:e53.

21. Mead S, Mahal SP, Beck J, Campbell T, Farrall M, Fisher E, Collinge J: Sporadic-but not variant-Creutzfeldt-Jakob disease is associated with polymorphisms upstream of PRNP exon I. Am J Hum Genet 200I, 69: I225-1235.

22. Croes EA, Alizadeh BZ, Bertoli-Avella AM, Rademaker T, VergeerDrop J, Dermaut B, Houwing-Duistermaat JJ, Wientjens DP, Hofman A, Van Broeckhoven C, van Duijn CM: Polymorphisms in the prion protein gene and in the doppel gene increase susceptibility for Creutzfeldt-Jakob disease. Eur J Hum Genet 2004, 1 2:389-394.

23. Jeong BH, Lee KH, Lee YJ, Kim YH, Cho YS, Carp RI, Kim YS: PRNP 1368 polymorphism is not associated with sporadic Creutzfeldt-Jakob disease in the Korean population. Eur J Neurol 2008, 15:846-850.

24. Rohrer JD, Mead S, Omar R, Poulter M, Warren JD, Collinge J, Rossor $\mathrm{MN}$ : Prion protein (PRNP) genotypes in frontotemporal lobar degeneration syndromes. Ann Neurol 2006, 60:616.

25. McKhann G, Drachman D, Folstein M, Katzman R, Price D, Stadlan $E M$ : Clinical diagnosis of Alzheimer's disease: report of the NINCDS-ADRDA Work Group under the auspices of Department of Health and Human Services Task Force on Alzheimer's Disease. Neurology 1984, 34:939-944.

26. American Psychiatric Association, Diagnostic and Statistical Manual of Mental Disorders. Fourth edition. (DSM-IV), Washington, DC; 1994:143-147.

27. Roman GC, Tatemichi TK, Erkinjuntti T, Cummings JL, Masdeu JC Garcia JH, Amaducci L, Orgogozo JM, Brun A, Hofman A, Moody DM, O'Brien MD, Yamaguchi T, Grafman J, Drayer BP, Bennett DA, Fisher M, Ogata J, Kokmen E, Bermejo F, Wolf PA, Gorelick PB, Bick KL, Pajeau AK, Bell MA, DeCarli C, Culebras A, Korczyn AD, Bogousslavsky J, Hartmann A, Scheinberg P: Vascular dementia: diagnostic criteria for research studies. Report of the NINDSAIREN International Workshop. Neurology 1993, 43:250-260.

28. Stephens M, Smith NJ, Donnelly P: A new statistical method for haplotype reconstruction from population data. Am J Hum Genet 200I, 68:978-989. 
29. Jeong BH, Nam JH, Lee Y], Lee KH, Jang MK, Carp RI, Lee HD, Ju YR, Jo SA, Park KY, Kim YS: Polymorphisms of the prion protein gene (PRNP) in a Korean population. J Hum Genet 2004, 49:319-324.

30. Jeong BH, Lee KH, Jeong YE, Hwang KA, Lee YJ, Carp RI, Ju YR, Kim YS: Polymorphisms at codons 129 and 219 of the prion protein gene (PRNP) are not associated with sporadic Alzheimer's disease in the Korean population. Eur J Neurol 2007, 14:62I-626.

3I. Jeong BH, Na HR, Bae JC, Lee KH, Lee YJ, Kim NH, Song JH, Carp RI, Kim YS: Absence of association between codon 129 and 219 polymorphisms of the prion protein gene and vascular dementia. Dement Geriatr Cogn Disord 2007, 24:86-90.

32. Jeong BH, Lee YJ, Kim NH, Carp RI, Kim YS: Genotype distribution of the prion protein gene (PRNP) promoter polymorphisms in Korean cattle. Genome 2006, 49:1539-1544.

33. Kashkevich K, Humeny A, Ziegler U, Groschup MH, Nicken P, Leeb $T$, Fischer C, Becker CM, Schiebel K: Functional relevance of DNA polymorphisms within the promoter region of the prion protein gene and their association to BSE infection. FASEB J 2007, 21 : I547-1555.

34. Jeong BH, Sohn HJ, Lee JO, Kim NH, Kim JI, Lee SY, Cho IS, Joo YS, Carp RI, Kim YS: Polymorphisms of the prion protein gene (PRNP) in Hanwoo (Bos taurus coreanae) and Holstein cattle. Genes Genet Syst 2005, 80:303-308.

35. Sander P, Hamann H, Drögemüller C, Kashkevich K, Schiebel K, Leeb $\mathrm{T}$ : Bovine prion protein gene (PRNP) promoter polymorphisms modulate PRNP expression and may be responsible for differences in bovine spongiform encephalopathy susceptibility. J Biol Chem 2005, 280:37408-374I4.

36. Bueler H, Aguzzi A, Sailer A, Greiner RA, Autenried P, Aguet M, Weissmann C: Mice devoid of PrP are resistant to scrapie. Cell 1993, 73:1339-1347.

37. Westaway D, Mirenda CA, Foster D, Zebarjadian Y, Scott M, Torchia M, Yang SL, Serban H, DeArmond SJ, Ebeling C, Prusiner SB, Carlson GA: Paradoxical shortening of scrapie incubation times by expression of prion protein transgenes derived from long incubation period mice. Neuron 1991, 7:59-68.

38. McCormack JE, Baybutt HN, Everington D, Will RG, Ironside JW, Manson JC: PRNP contains both intronic and upstream regulatory regions that may influence susceptibility to Creutzfeldt-Jakob Disease. Gene 2002, 288:|39-| 46.

39. Bratosiewicz-Wasik J, Liberski PP, Golanska E, Jansen GH, Wasik TJ: Regulatory sequences of the PRNP gene influence susceptibility to sporadic Creutzfeldt-Jakob disease. Neurosci Lett 2007, 4I I:163-I67.

\section{Pre-publication history}

The pre-publication history for this paper can be accessed here:

http://www.biomedcentral.com/1471-2350/10/32/pre pub

\section{Publish with Bio Med Central and every scientist can read your work free of charge}

"BioMed Central will be the most significant development for disseminating the results of biomedical research in our lifetime. "

Sir Paul Nurse, Cancer Research UK

Your research papers will be:

- available free of charge to the entire biomedical community

- peer reviewed and published immediately upon acceptance

- cited in PubMed and archived on PubMed Central

- yours - you keep the copyright

Submit your manuscript here:

http://www.biomedcentral.com/info/publishing_adv.asp
BioMedcentral 